\title{
Pelatihan Pembuatan Handycraft Dari Limbah Biota Laut
}

\author{
Hariana $^{1)}$, Rahmatiah') \\ ${ }^{1}$ Jurusan Seni Rupa dan Desain, Universitas Negeri Gorontalo \\ ${ }^{2}$ Jurusan Sosiologi, Universitas Negeri Gorontalo \\ Email: hariana@ung.ac.id
}

\begin{abstract}
ABSTRAK
Biota laut dikenal sebagai sekumpulan berbagai speces hewan, tumbuhan, atau karang yang hidup di laut sebagai tempat perkembangbiakannya. Salah satu manfaat dari biota laut adalah pemanfaatan limbah biota laut menjadi produk karya seni. Melalui KKN Tematik UNG Tahun 2020 menjadi program inti mahasiswa KKN di Desa Pilohulata Kecamatan Monano Kabupaten Gorontalo Utara dengan memberikan pelatihan pembuatan handycraft dari limbah biota laut. Pelaksanaan pelatihan bertujuan membekali pengetahuan dan keterampilan dengan memanfaatkan limbah biota laut menjadi berbagai karya seni menggunakan teknik kolase. Bentuk karya seni yang dihasilkan adalah bingkai foto, aksesoris dan kotak serbaguna. Kegiatan KKN Tematik UNG diharapkan dapat berorientasi menjadi peluang usaha yang bertujuan meningkatkan ekonomi masyarakat Desa Pilohulata. Kelompok sasaran kegiatan pelatihan adalah remaja muda yang belum mempunyai pekerjaan tetap. Luaran dari kegiatan pelatihan adalah: (1) menumbuhkan minat berkarya kepada peserta pelatihan dalam mengolah limbah biota laut menjadi karya yang bernilai ekonomi; (2) limbah biota laut menjadi handycraft yang bernilai fungsi: (3) memanfaatkan limbah biota laut menjadi peluang usaha; dan (4) membentuk kelompok-kelompok usaha kecil menengah dan mengembangkan jiwa entrepreneur bagi peserta pelatihan.
\end{abstract}

\section{Kata Kunci: Biota Laut, Handycraft, Limbah}

\section{ABSTRACT}

Marine life is known as a collection of various species of animals, plants or corals that live in the sea as a place for their breeding. One of the benefits of marine life is the use of marine biota waste into art products. Through the 2020 UNG Thematic KKN, it becomes the core program for KKN students in Pilohulata Village, Monano District, North Gorontalo Regency by providing training in making handicrafts from marine biota waste. The training aims to equip knowledge and skills by utilizing marine biota waste into various works of art using collage techniques. The resulting art forms are photo frames, accessories and multipurpose boxes. UNG Thematic KKN activities are expected to be oriented to become business opportunities aimed at improving the economy of the Pilohulata Village community. The target group for training activities are young adolescents who do not have permanent jobs. The output of the training activities are: (1) fostering interest in work among training participants in processing marine biota waste into works of economic value; (2) marine biota waste becomes handicraft with the following functions: (3) utilizing marine biota waste into business opportunities; and (4) forming small and medium enterprise groups and developing an entrepreneurial spirit for the training participants.

\section{Keywords: Marine Biota, Handycraft, Waste}




\section{PENDAHULUAN}

Wilayah Perairan laut yang dimiliki Indonesia lebih luas daripada wilayah daratannya, sehingga wilayah laut penting menjadi perhatian bagi kehidupan masyarakat (Tinambunan, 2016). Indonesia dikenal dunia sebagai Negara kepulauan terbesar dengan jumlah 17.508 pulau dengan garis pantai sepanjang $81.791 \mathrm{~km}$ menyebar dan membentang dari sabang sampai Marauke (Lubis, 2014). Desa pesisir pantai yang menjadi lokasi Kuliah Kerja Nyata (KKN) Pengabdian Universitas Negeri Gorontalo adalah desa Pilohulata kecamatan Monano kabupaten Gorontalo Utara masuk pada wilayah di Teluk Tomini.

Potensi daerah di desa Pilohulata memiliki luas pertanian non sawah adalah 2132 hektar. Berdasarkan hasil survei bahwa desa Pilohulata terdapat pesisir pantai dan juga pengunungan. Secara Umum, pembangunan infrastruktur sangat terbatas di desa Pilohulata terutama infrastruktur pendidikan dan kesehatan. Hal tersebut tampak pada sajian data Kecamatan Monano dalam Angka 2018, yakni sekolah yang tersedia hanya satu sekolah PAUD sedangkan SD, SMP, dan SMA tidak ada di Desa Pilohulata.

Ambariyanto dan N.S (2012) menyampaikan bahwa terdapat empat masalah yang selalu dihadapi masyarakat pesisir di Indonesia yakni: 1) tingginya tingkat kemiskinan masyarakat pesisir; 2) tingginya kerusakan sumber daya pesisir; 3 ) rendahnya kemandirian organisasi sosial desa dan lunturnya nilai-nilai; 4) kurangnnya infrastruktur desa dan kesehatan lingkungan pemukiman (Tinambunan, 2016). Kondisi ini memperkuat pandangan Qodriyatun (2013) bahwa penduduk di daerah perkotaan lebih menikmati pembangunan infrastuktur dan pertumbuhan ekonomi dibandingkan dengan penduduk di wilayah pesisir, dan makin mempertajam kesenjangan ekonomi dan sosial. Kondisi tersebut juga sangat dirasakan oleh masyarakat di desa Pilohulata.

Dibalik kesenjangan dan keterbatasan yang dihadapi masyarakat desa Pilohulata, menyimpan begitu banyak potensi sumber alam hayati termasuk biota lautnya. Kecamatan Monano yang sepanjang jalan merupakan pesisir pantai menjadi alasan menjadikan biota laut sebagai media berkarya mahasiswa KKN UNG sebagai kegiatan inti. Dasar pentingnya memanfaatkan biota laut difokuskan pada limbahnya yang gampang dan banyak ditemukan di pesisir pantai untuk dijadikan sumber ide dalam melakukan ekperimen kreatif menjadi aktivitas ekonomi alternatif bertujuan meningkatkan pengetahuan, skill, kemandirian, dan peningkatan ekonomi bagi masyarakat pesisir.

Biota laut merupakan sekumpulan speces dari flora, fauna, tumbuhan, dan hewan yang hidup di laut sebagai tempat perkembangbiakannya (Diyanti, 2017). Jenis-jenis limbah biota laut yang digunakan membuat handycraft sebagai bahan baku seperti kerang, keong, bintang laut, karang dan jenis lain yang ditemukan di pesisir pantai di kecamatan Monano. Teknik kolase (teknik tempel) adalah salah satu teknik dengan pengerjaan menggunakan handmade dan semi manual dalam menciptakan dan mengeksplorasi karyakarya kreatif dari bahan limbah biota laut. Mengapa teknik kolase menjadi pilihan, karena masyarakat peserta pemberdayaan adalah masyarakat dengan tingkat pendidikan yang rendah, sehingga dicari teknik yang mudah, praktis, dan tidak beresiko, tetapi mendapatkan karya yang indah dan bernilai ekonomi.

\section{Gambaran Umum Situasi}

Berdasarkan data dalam Kecamatan Mananggu Dalam Angka 2018, prentase luas wilayah kecamatan Monano dari Gorontalo Utara adalah 81\%, sedangkan presentase penduduk kabupaten Gorontalo berdasarkan kecamatan, yaitu kecamatan 
Monano 6\%. Wilayah di Kecamatan Monano terdapat 10 Desa, salah satunya yang menjadi lokasi KKN Tematik UNG tahun 2020 adalah Desa Pilohulata. Berdasarkan data statistik Kecamatan Monano dalam Angka 2018 bahwa jumlah penduduk berjenis kelaman laki-laki adalah 254 jiwa dan jenis kelamin perempuan 243 jiwa. Penduduk desa Pilohulata sangat homogen yang dapat diamati dari wilayahnya dihuni oleh masyarakat yang mayoritas beragama Islam dan ditandai tempat ibadah yang tersedia adalah 2 masjid. Perilaku sosial masyarakatnya tetap terbangun dan terpelihara sebagai bentuk solidaritas mekanik sesama masyarakat.

\section{Permasalahan Mitra}

Kecamatan Monano dikenal sebagai daerah pesisir pantai yang besebelahan dengan pengunungan. Pesisir pantai belum sepenuhnya menjadi objek wisata masyarakat sekitanya. Salah satu limbah pantai yang dapat dijadikan karya yang bernilai seni dan bernilai ekonomi adalah limbah biota laut. Biota laut dapat ditemuakan sekitar pantai dengan beragam macam jenis. Masyarakat yang berjiwa seni dapat memanfaatkan limbah biota laut menjadi suatu karya yang berfungsi ganda. Melalui KKN Tematik tahun 2020 telah membekali keterampilan bagi masyarakat di desa Pilohulata untuk memanfaatkan limbah biota laut menjadi kerajinan tangan yang bernilai seni dan bernilai ekonomi bagi masyarakatnya.

\section{SOLUSI DAN TARGET LUARAN}

\section{Solusi Permasalahan}

Capaian dari kegiatan Program Kuliah Kerja Nyata (KKN) Tematik Tahun 2020 di Desa Pilohulata Kecamatan Monano Kabupaten Gorontalo Utara adalah:

1. Menumbuhkan kesadaran, minat, pengetahuan dan keterampilan kepada masyarakat pesisir dalam mengolah limbah biota laut menjadi handycraft .

2. Memanfaatkan limbah biota laut menjadi produk kerajinan tangan yang dapat menjadi peluang usaha masyarakat pesisir di desa Pilohulata Kecamatan Monano Kabaupaten Gorontalo Utara.

3. Mengembangkan pengetahuan dan keterampilan yang diperoleh dengan mengkolaborasikan dari sumbersumber bacaan, baik melalui buku, hasil penelitian, atupun dari media-media sosial.

4. Membentuk kelompok-kelompok usaha kecil dan mengembangkan jiwa entrepreneur bagi peserta pelatihan masyarakat pesisir di desa Pilohulata Kecamatan Monano Kabupaten Gorontalo Utara.

\section{Luaran dan Target Capaian}

Luaran dari kegiatan Kuliah Kerja Nyata (KKN) Tematik UNG yang diikuti oleh mahasiswa Universitas Negeri Gorontalo adalah mempublikasikan hasil kegiatan pelatihan yang telah diberikan kepada masyarakat Pesisir di di desa Pilohulata Kecamatan Monano Kabupaten Gorontalo Utara. Produk yang dihasilkan dari mahasiswa KKN Tematik Tahun 2020 adalah kerajinan tangan berupa bingkai foto, aksesoris, hiasan dinding, dan kotak serbaguna. Mahasiswa KKN Tematik melaksanakan seminar hasil kegiatan yang telah dilaksanakan dengan membuat laporan kegiatan atau jurnal baik secara individu maupun secara kelompok.

Laporan hasil kegiatan mahasiswa KKN Tematik, dinilai oleh Dosen Pendamping Lapangan (DPL) dan selanjutnya akan dilaporkan ke Pihak LPPM UNG.

\section{Rencana Keberlanjutan Program}

Perencanaan jangka panjang yang dilakukan dalam upaya menjaga keberlanjutan program KKN Tematik ini adalah kegiatan pelatihan menjadi salah satu 
kegiatan Bumdes Pilohulata. Pada awal pelaksanaan program yang dilakukan adalah memberdayakan masyarakat dalam mengolah limbah biota laut menjadi benda pakai yang bernilai estetika. Bentuk kegiatan pelatihan yang dilaksanakan di Desa Pilohulata Kecamatan Monano Kabupaten Gorontalo Utara adalah mengolah limbah biota laut menjadi produk kerajinan tangan. Tujuan dari pelatihan yang dilaksanakan di pesisir pantai Desa Pilohulata adalah sebagai upaya memberdayaan masyarakat dalam mengolah limbah sehingga termanfaatkan secara optimal dan memberikan kesejahteran sosial dan peningkatan ekonomi masyarakatnya.

Keberlanjutan program dengan melakukan pendampingan dalam penguatan kualitas produksi, inovasi produk dan teknologi, pengemasan, dan pemasarannya dengan bekerja sama dengan pihak-pihak yang terkait dalam mensukseskan programprogram desa yang mengusung pembangunan partisipatif "Oleh masyarakat dan untuk masyarakat". Pengabdian masyarakat sebagai salah satu unsur kewajiban bagi Dosen untuk dilaksanakan. Salah satu program Perguruan Tinggi Universitas Negeri Gorontalo Tahun 2020 adalah KKN Tematik yang didanai melalui dana PNBP untuk mendukung program pengabdian masyarakat terutama dalam kegiatan penyadaran kepada masyarakat dalam meningkatkan kualitas dari seluruh elemen dalam pengembangan desa khususnya.

\section{METODE PELAKSANAAN KEGIATAN}

Mahasiswa KKN mendata calon peserta pelatihan sejumlah 20 orang. Peserta yang didata berjumlah 20 orang diminta kesediannya untuk dapat mengikuti pelatihan dari awal sampai selesai. Harapan dari mahasiswa KKN juga disampaikan kepada calon peserta pelatihan jika nantinya setiap peserta dapat menghasilkan minimal satu karya dalam kegiatan pelatihan.
Mahasiswa KKN membentuk kelompok kerja untuk mendampingi peserta pelatihan yang direncanakan. Sebelum kegiatan pelatihan dimulai, Dosen Pendamping Lapangan memberi arahan kepada seluruh mahasiswa KKN mengenai strategi pendampingan yang akan diberikan kepada peserta pelatihan.

\section{HASIL DAN PEMBAHASAN}

Langkah awal pelaksanaan kegiatan pelatihan dimulai dari mendata peserta pelatihan. Peserta yang didata berjumlah 20 orang terdiri dari masyarakat produktif baik golongan remaja, ibu rumah tangga, dan remaja muda. Pelatihan dilaksanakan pada hari Minggu tanggal 20 September 2020 di aula kantor desa Pilohulata, dimulai pukul 09.00 sampai selesai. Sebelum kegiatan pelatihan dimulai, Dosen Pendamping Lapangan memberi arahan kepada dengan seluruh mahasiswa KKN mengenai strategi pendampingan yang akan dilaksanakan.

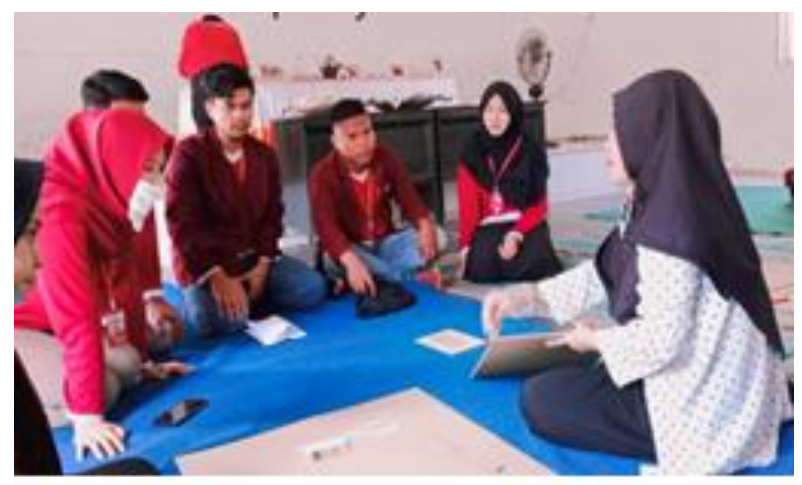

Gambar 1. Pendampingan dari DPL Sebelum Pelatihan dimulai

Ketika peserta pelatihan telah berkumpul, kegiatan pelatihan dimulai diawali dengan laporan dari kordes, sambutan dari kepala desa, sambutan dari sekertaris BPD, dan sambutan dari Dosen Pendamping Lapangan. 


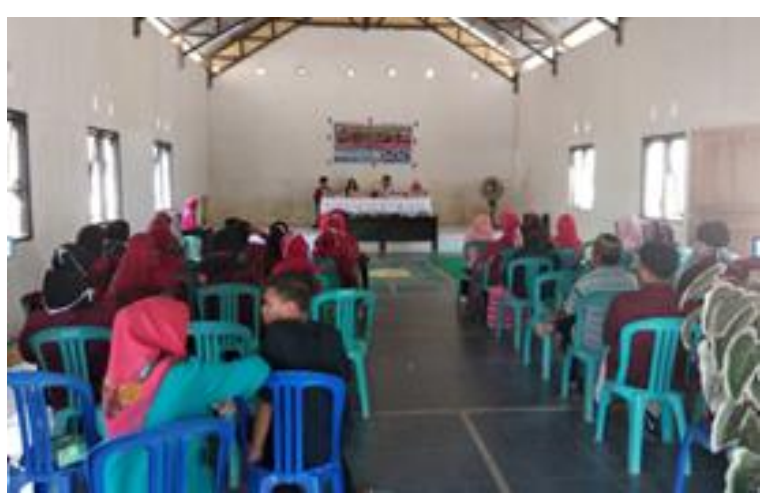

Gambar 2. Sambutan dari Kepala Desa Pilohulata

Kegiatan pelatihan dihadiri oleh kepala desa Pilohulata, sekretaris desa dan aparatnya, ketua dan sekretaris BPD, anggota LPM desa Pilohulata, ketua karang taruna, dan tokoh masyarakat desa Pilohulata. Kegiatan pelatihan dirancang mahasiswa KKN dengan sistem kerja kelompok. Peserta 20 orang dibagi menjadi tiga kelompok, masing-masing kelompok didampimgi oleh mahasiswa KKN.

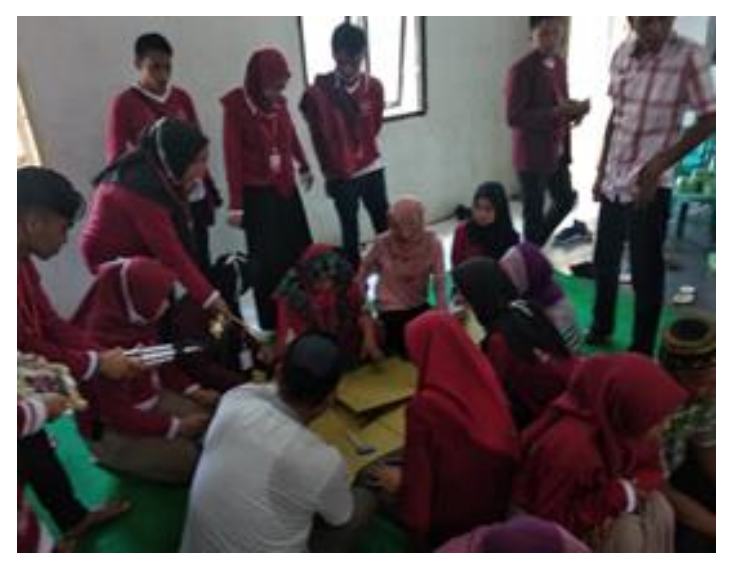

Gambar 3. Mahasiswa KKN Mendampingi Peserta Pelatihan

Tugas dari mahasiwa KKN dalam kelompok peserta pelatihan adalah membimbing dan mengarahkan dalam membuat handycraft limbah biota laut. Kerja secara kelompok yang dirancang oleh mahasiswa KKN menjadikan kegiatan lebih dapat dikontrol.

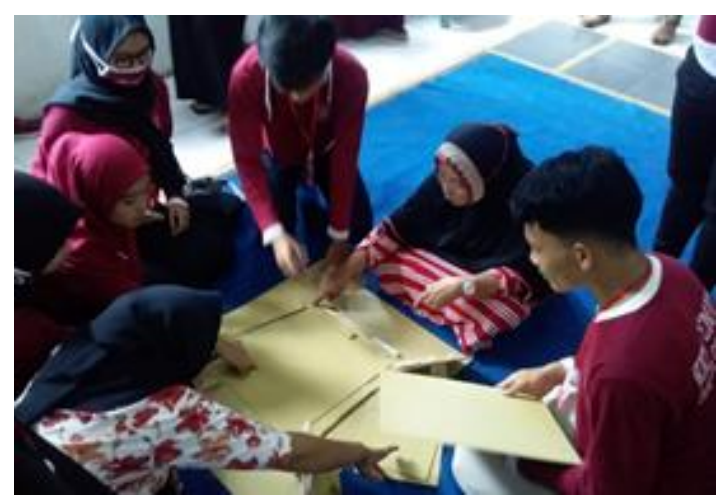

Gambar 4. Mahasiwa Memberi Arahan Kepada Peserta Pelatihan

Pelatihan yang dilaksanakan mahasiswa KKN didukung oleh masyarakat, ditandai dengan kehadiran pihak-pihak terkait dalam kegiatan pelatihan. Disela kegiatan pelatihan, mahasiswa berkesempatan mewawancarai kepala desa Pilohulata, ketua BPD, ketua karang taruna, kordes, dan salah satu peserta.

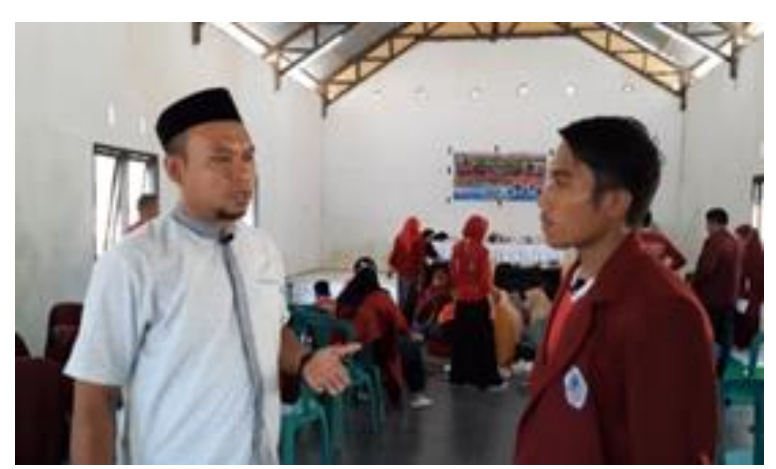

Gambar 5. Kepala Desa Pilohulata Merespon Baik Kegiatan Pelatihan

Pada akhir kegiatan, peserta pelatihan melihat hasil karyanya sehingga menimbulkan rasa ingin membuat lagi dengan kreasi-kreasi yang berbeda. Kegiatan ini memberi manfaat ganda karena selain mengurangi limbah biota laut juga dapat menjadi kegiatan yang menghasilkan apabila diperjual belikan. 


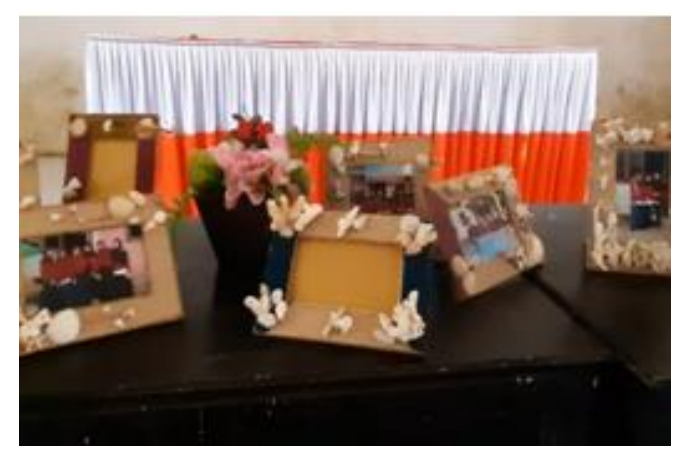

Gambar 6. Hasil Karya Peserta Pelatihan

Kepala desa Pilohulata dan masyarakatnya berharap jika nantinya keterampilan yang sudah didapatkan menjadi salah satu program desa, mengingat bahan bakunya, yaitu limbah biota laut dapat diperoleh tanpa membeli dan bahkan mengurangli limbah pantai. Akhir dari kegiatan pelatihan adalah foto bersama peserta pelatihan dan masyarakat yang hadir dalam kegiatan pelatihan.

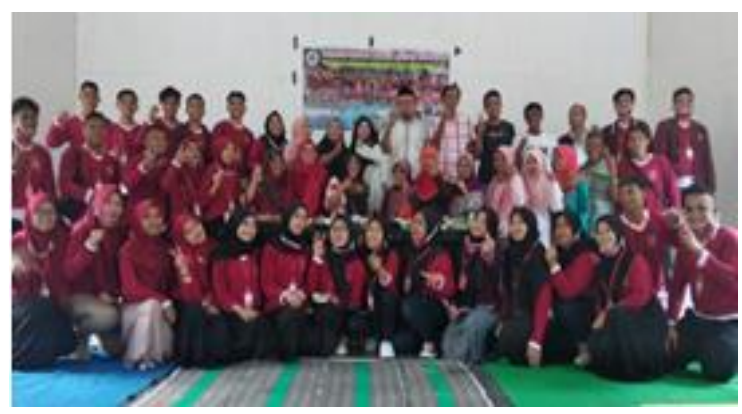

Gambar 7. Foto Bersama Setelah Kegiatan Pelatihan Selesai

Kegiatan pelatihan yang dilaksanakan mahasiswa KKN desa Pilohulata dinilai memberi motivasi peserta pelatihan dalam berkarya, ditandai dengan peserta tetap bertahan peraktek hingga sore hari.

\section{KESIMPULAN DAN SARAN}

Masyarakat Desa Pilohulata lebih kreatif dalam membuat kerajinan tangan dari biota laut yang ditandai dengan hasil yang dibuat dari kegiatan inti lebih variatif. Kegiatan tersebut didasarkan atas adanyanya contoh karya yang sudah jadi sebagai contoh. Contoh karya yang ada menjadikan peserta pelatihan menjadi termotivasi untuk membuat lebih baik lagi dari nilai estetika dan nilai jual. Contohcontoh tersebut menjadi sumber ide masyarakat untuk menciptakan model kerajinan tangan yang lebih variatif lagi. Beragamnya hasil karya yang dihasilkan menjadikan program pelatihan tercapai menciptakan produk bernilai seni. Kegiatan pelatihan pembuatan kerajinan tangan berupa bingkai foto dan kotak serbaguna dari limbah biota laut, didukung oleh Karang Taruna menjadi salah satu kegiatan masyarakat Desa Pilohulata.

\section{DAFTAR PUSTAKA}

Ambariyanto, \& N.S, D. (2012). Kajian Pengembangan Desa Pesisir Tangguh di Kota Semarang. Riptek, 6 (II), 2938.

Diyanti, K. (2017). Biota Laut Sebagai Sumber Ide Pembuatan Cendera Mata Logam Wisata Pantai Pasir Putih Kabupaten Situbondo. Jurnal Seni Rupa, 05(03).

Kecamatan Mananggu Dalam Angka 2018. (2018d.)https://boalemokab.bps.go.id/ publication/2018/09/26/3473c40593bd 22ed97d35022/kecamatan-mananggudalam-angka-2018.html

Lubis, Y. A. (2014). Studi Tentang Aktivitas Ekonomi Masyarakat Pesisir Pantai Pelabuhan. Jurnal Ilmu Pemerintahan, 2 (2), 133-140.

Qodriyatun, S. N. (2013). Peningkatan Kesejahteraan Masyarakat Pesisir Di Kota Batam Melalui Pemberdayaan Masyarakat. Jurnal Aspirasi, 4 (2), 91100.

Tinambunan, H. S. R. (2016). Pemberdayaan Masyarakat Pesisir Melalui penguatan Budaya Maritim dalam Menghadapi Pasar Bebas Masyarakat Ekonomi Asean. Jurnal Fiat Justisia, 10(1). fh.unila.ac.id/index.php/flat 